\title{
Cocaine-Induced Increases in EEG Alpha and Beta Activity: Evidence for Reduced Cortical Processing
}

Ronald I. Herning, Ph.D., Barbara J. Glover, R.N., Bonnie Koeppl, M.A., Robert L. Phillips, Ph.D., and Edythe D. London, Ph.D.

To understand the effects of cocaine on the cerebral cortex, 14 male polydrug abusers were enrolled in a study on the effects of cocaine on the electroencephalogram (EEG). The experimental treatments were placebo, $20 \mathrm{mg}$ cocaine or $40 \mathrm{mg}$ cocaine IV administered in a doubleblind, pseudorandom design. The EEG was recorded from 13 electrode positions over the left hemisphere during a 3-minute baseline recording and for 30 minutes after initiation of the IV injection. The spectral power for delta, theta, alpha and beta EEG bands was calculated from data collected in each 3-minute interval. Cocaine significantly increased beta in frontal and central areas and enhanced alpha in frontal and temporal regions. Cocaine-induced increases in EEG beta power had a cortical distribution similar to those produced by barbiturates and benzodiazepines. As all of these drugs reduce cortical glucose metabolism, the increases in beta power may reflect a reduction in cortical neural activity. [Neuropsychopharmacology 11:1-9, 1994]

\section{KEY WORDS: Cocaine; EEG; Drug abuse}

Despite the epidemic of cocaine abuse during the past two decades, little is known about the neurophysiological effects of this drug in humans. Berger, the first to study effects of cocaine on the human EEG, noted that $30 \mathrm{mg}$ of subcutaneous cocaine increased EEG alpha abundance in two subjects (Berger 1931). Using an amplifier that allowed the recording of EEG in the beta frequency range, he later observed an increase in EEG beta

From the Medical Affairs Branch (RIH, BJG, BK) and Neuroimaging and Drug Action Section (RLP, EDL), Neuroscience Branch, Addiction Research Center, National Institute on Drug Abuse, National Institutes of Health, Baltimore, Maryland; Department of Radiology (EDL), The Johns Hopkins School of Medicine and The Department of Pharmacology and Experimental Therapeutics, School of Medicine, University of Maryland, Baltimore, Maryland.

Address correspondence to: Ronald I. Herning, Ph.D., Medical Affairs Branch, Addiction Research Center, P.O. Box 5180, Baltimore, MD 21224

Received September 17, 1993; revised February 22, 1994; accepted February 24, 1994. in one subject who received $20 \mathrm{mg}$ cocaine subcutaneously (Berger 1937). Herning et al. (1985) replicated the observation that cocaine increased EEG beta in a large sample of subjects who received intravenous (IV) and oral cocaine. Both Berger and Herning interpreted the increase in EEG beta as an indication of increased cortical arousal.

Increases in EEG beta do not always indicate increased cortical arousal or activity. Whereas barbiturates and benzodiazepines increase EEG beta activity in frontal and central areas (Benowitz et al. 1980; Domino et al. 1989; Manmaru et al. 1989), both classes of drugs also reduce cerebral glucose utilization (Theodore et al. 1986; Buchsbaum et al. 1987; Foster et al. 1987; de Wit et al. 1991), an index of brain function (Sokoloff 1972). Amphetamine and cocaine also reduce cortical glucose metabolism and blood flow in human subjects (Wolkin et al. 1987; Kahn et al. 1989; London et al. 1990). The view that increases in EEG beta, produced by stimulant drugs in human subjects, may reflect decreased cortical activation agrees with observations that dopamine, norepinephrine, and indirect dopaminergic agonists de- 
crease neuronal firing in mesolimbic areas of the rodent brain (Bunney and Aghajanian 1978; Siggins 1978).

The present report investigates the anterior-posterior distribution of cocaine-induced changes in the human EEG. Since the EEG beta changes produced by the drugs noted above were either maximal in frontal areas or were observed first in frontal areas and were not asymmetric (Benowitz et al. 1980; Domino et al. 1989; Manmaru et al. 1989), we concentrated our limited EEG recording capacity on the left hemisphere. One objective of this work was to assess the potential relationship between self-reports of alterations in mood and EEG effects of cocaine in different cortical areas. Previous studies used only a limited number of recording sites and short EEG recording periods. We now report the EEG changes from 13 sites before and continuously for 30 minutes after the injection of placebo, and 20and 40-mg IV l-cocaine hydrochloride.

\section{MATERIALS AND METHODS}

\section{Subjects}

Eighteen men were recruited for this study, with cocaine abuse as an inclusionary criterion. One subject was excluded because of a subarachnoid cyst noted on magnetic resonance imaging (MRI), and the EEG data from three subjects were incomplete either because of technical difficulties of unusual sensitivity to a test dose of $20 \mathrm{mg}$ cocaine. Characteristics of the 14 subjects who completed the study are listed in Table 1 . Self-reports of drug abuse were obtained by an interview using a two-page questionnaire developed at the Addiction Research Center and administered in conjunction with the Addiction Severity Index (McLellan et al. 1985) (Table 2). Aside from substance abuse, all subjects were healthy as determined by a physical examination, including electrocardiogram and standard diagnostic laboratory tests. They were screened for psychiatric disorders by the National Institute on Mental Health Diagnostic Interview Schedule, which was adapted for computerized administration (Robins et al. 1981). Diagnostic criteria were defined according to the DSMIII. The only current Axis I diagnoses for which subjects met criteria were substance abuse disorders. The only Axis II diagnoses that were allowed were borderline and/or antisocial personality disorders. Three subjects were diagnosed as having antisocial personality disorder and none met criteria for borderline personality disorder. All subjects were seronegative for human immunodeficiency virus (HIV-I), as determined by ELIZA and Western blots. They were all right-handed, as measured by a questionnaire (Annett 1970). All subjects gave written informed consent according to procedures outlined by the institutional review boards of Johns Hopkins Medical Institutions and Francis Scott
Table 1. Demographic Characteristics of the Subjects

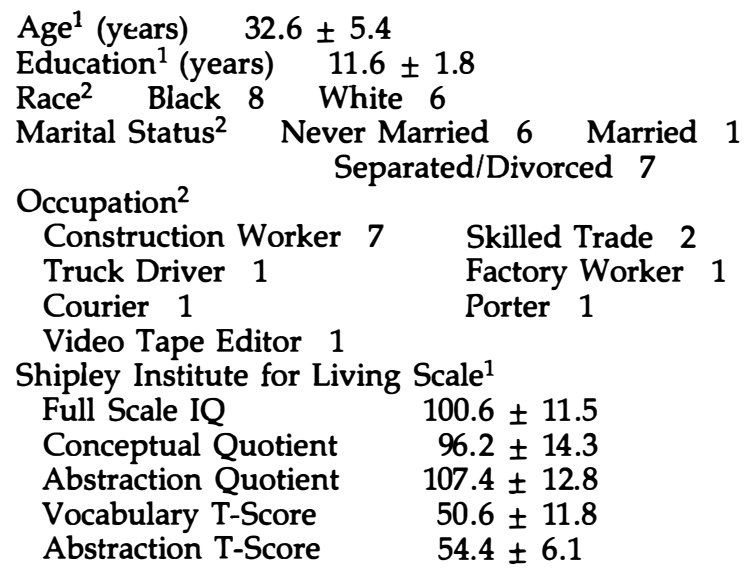

\footnotetext{
${ }^{1}$ Values shown are mean and standard deviations.

2 Values shown are numbers of subjects in each category.
}

Key Medical Center, a Hopkins-affiliated hospital where the Addiction Research Center is located.

Among the many difficulties with studies that involve administration of cocaine to human subjects is the variability in drug use by nonresidential research subjects. Therefore, subjects in the current study resided on a limited-access research ward, with screening of urine to detect and exclude self-administration of abused drugs. Except for nicotine and caffeine, which were available in cigarettes and beverages, respectively, the subjects were drug-free for 6 to 16 days (mean 9.4 \pm 3.1 days) before testing began in the study. After EEG testing, with 0,20 , and $40 \mathrm{mg}$ IV cocaine, subjects participated in measurement of regional cerebral metabolic rates for glucose by the $\left[{ }^{18} \mathrm{~F}\right]$ fluorodeoxyglucose positron emission tomographic (PET) method. The effect of $40 \mathrm{mg}$ cocaine versus placebo, as determined by PET scanning, in eight of the subjects who participated in the present study has been reported (London et al. 1990).

\section{Experimental Design}

Each subject was tested four times. The test sessions were separated by at least 24 hours. The first session was used to familiarize the subject with the testing environment. The first treatment always was a placebo IV injection that was given in a single-blind manner. Only heart rate, blood pressure, and subjective effects were monitored. EEG was recorded during the next three sessions. Placebo, $20 \mathrm{mg}$, and $40 \mathrm{mg}$ cocaine were administered in a double-blind, pseudorandom sequence. The $20 \mathrm{mg}$ dose was always given before the $40 \mathrm{mg}$ dose, but placebo occurred randomly in the sequence. This sequence was used to protect the subjects from possible adverse effects of the higher dose of cocaine. 
Table 2. Self-Reported Drug Use History

\begin{tabular}{|c|c|c|c|c|}
\hline Drug & $\begin{array}{l}\text { Number of Subjects } \\
\text { with Lifetime }{ }^{1 /} \\
\text { Current }{ }^{2} \text { Use }\end{array}$ & $\begin{array}{l}\text { Age of First } \\
\text { Use (years) }\end{array}$ & $\begin{array}{l}\text { Number of Days } \\
\text { in Last } 2 \text { Weeks }^{3}\end{array}$ & $\begin{array}{c}\text { Recent Use } \\
\text { Amount/14 Days }\end{array}$ \\
\hline Cocaine & $14 / 13$ & $\begin{array}{r}21.3 \pm 5.5 \\
(13 \text { to } 35)\end{array}$ & $\begin{array}{l}5.1 \pm 3.0 \\
(1 \text { to } 10)\end{array}$ & $\begin{array}{l}0.6 \pm 0.5 \mathrm{~g} \\
(0.1 \text { to } 2.0)\end{array}$ \\
\hline Amphetamine & $4 / 2$ & $\begin{array}{r}21.6 \pm 0.9 \\
(16 \text { to } 25)\end{array}$ & $\begin{array}{l}4.5 \pm 3.1 \\
(1 \text { to } 8)\end{array}$ & $\begin{array}{l}0.5 \pm 0.3 \mathrm{~g} \\
(0.2 \text { to } 0.8)\end{array}$ \\
\hline Heroin & $12 / 7$ & $\begin{array}{l}18.8 \pm 3.6 \\
(15 \text { to } 25)\end{array}$ & $\begin{array}{l}4.7 \pm 3.1 \\
(1 \text { to } 10)\end{array}$ & $\begin{array}{l}0.1 \pm 0.1 \mathrm{~g} \\
(0.05 \text { to } 0.1)\end{array}$ \\
\hline Barbiturates & $4 / 1$ & $\begin{array}{r}16.8 \pm 2.1 \\
(15 \text { to } 20)\end{array}$ & 1.0 & $200 \mathrm{mg} /$ day \\
\hline Hallucinogens & $7 / 0$ & $\begin{array}{l}16.3 \pm 1.1 \\
(15 \text { to } 18)\end{array}$ & & \\
\hline Marijuana & $14 / 9$ & $\begin{array}{l}15.4 \pm 3.5 \\
(12 \text { to } 25)\end{array}$ & $\begin{array}{l}5.4 \pm 3.5 \\
(2 \text { to } 12)\end{array}$ & $\begin{array}{c}1.1 \pm 13.2 \text { joints } \\
(2 \text { to } 40)\end{array}$ \\
\hline Alcohol & $14 / 13$ & $\begin{array}{c}14.3 \pm 1.8 \\
(12 \text { to } 17)\end{array}$ & $\begin{array}{l}5.7 \pm 4.8 \\
(1 \text { to } 14)\end{array}$ & $\begin{array}{c}8.0 \pm 5.0 \text { drinks } \\
(2 \text { to } 18)\end{array}$ \\
\hline Nicotine & $13 / 13$ & $\begin{array}{l}14.1 \pm 40.2 \\
(8 \text { to } 23)\end{array}$ & $\begin{array}{l}13.7 \pm 1.1 \\
(10 \text { to } 14)\end{array}$ & $\begin{array}{c}20.0 \pm 7.9 \text { cigarettes/day } \\
(10 \text { to } 30)\end{array}$ \\
\hline
\end{tabular}

\footnotetext{
${ }^{1}$ Number of subjects who used the drug.

${ }^{2}$ Number of subjects who are currently using the drug.

${ }^{3}$ Mean \pm standard deviation (range).
}

\section{Drug Treatments and Test Sessions}

The placebo dose was $2.0 \mathrm{ml}$ of $0.9 \% \mathrm{NaCl}$ (saline). The doses of cocaine were prepared by dissolving 20 or 40 $\mathrm{mg}$ of $l$-cocaine $\mathrm{HCl}$ in saline to an injection volume of $2.0 \mathrm{ml}$. They doses were infused intravenously over a period of 10 seconds, vital signs (electrocardiogram, blood pressure) and subjective ratings were monitored, and spontaneous EEG recorded in a sound-attenuated, electrically shielded chamber. Heart rate, systolic and diastolic blood pressure were recorded at 60 and 30 minutes before the injection and at $1,3,5,10,15,20$, and 30 minutes after the injection. A verbal response from " 0 " to " 4 ," indicating the strength of the drug effect, was elicited by a "beep" prompt at 60 -second intervals. The subject had a blindfold over his eyes and listened to white noise during the EEG recording procedure. A seven-item visual analog scale (VAS) also was used to monitor the subjective effects of cocaine (London et al. 1990). The VAS was administered at 30 and 60 minutes before the injection and at 30 minutes after the injection.

\section{EEG Recording and Analysis Procedures}

The EEG was recorded from the following International 10/20 scalp sites: $F_{p z}, F_{z}, C_{z}, P_{z}, O_{z}, F_{p 1}, F_{3}, C_{3}, P_{3}, O_{1}$, $\mathrm{O}_{z}, \mathrm{~F}_{7}, \mathrm{~T}_{3}$, and $\mathrm{T}_{5}$. The reference site was the tip of the left ear $\left(A_{1}\right)$. The electrooculogram (EOG) was recorded from above to the temporal side of the eye. Silver/silver chloride electrodes were used at all locations. The EEG and EOG were amplified using Grass (Model 7P511) amplifiers with $1-\mathrm{Hz}$ to $100 \mathrm{~Hz}$ half am- plitude band pass and a $60-\mathrm{Hz}$ notch filter. The amplifiers were calibrated with a $5-\mathrm{Hz}, 50-\mu$ volt square wave (Grass Calibrator, Model SWC1B). The calibration signal and EEG signals were input into amplifiers via the electrode board in the recording chamber. Their output was recorded on an IBM/AT personal computer with a Data Translation (Model DT2821-F-SE) analog to digital convertor. Each EEG or EOG channel was sampled at $5.0 \mathrm{msec}$ intervals using software developed in-house for this purpose. The interchannel sampling time was $40.0 \mu \mathrm{sec}$. A 3-minutepredrug recording (pre-) and a 30 -minute postdrug recording were obtained. The postdrug recording was synchronized with the starting of the 10-second IV injection period. The raw EEG and EOG data were saved for subsequent analysis.

A fast Fourier transform with a Tukey-Hamming window (Chamberlin 1985) was calculated on each 512 point sample (2.56 seconds) of artifact-free EEG data. EOG and movement artifact were rejected by a computer algorithm, as in Herning et al. (1985). The power spectra were resolved into $0.4-\mathrm{Hz}$ increments from 0.0 to $32.8 \mathrm{~Hz}$. The resultant power spectra were averaged for each 3-minute period (pre- and 10 postdrug average spectra). The power spectra were divided into the delta $(0.4$ to $4.0 \mathrm{~Hz})$, theta $(4.4$ to $8.0 \mathrm{~Hz})$, alpha $(8.4$ to $13.2 \mathrm{~Hz})$, and beta $(13.6$ to $32.8 \mathrm{~Hz}$ ) bands. Total spectral power $\left(\mu V^{2}\right)$ was measured in the respective bands. Left hemisphere topographic maps of banded EEG spectral power were constructed using the linear four point nearest-neighbor technique (Perrin et al. 1987). The changes from baseline in EEG spectral power in delta, theta, alpha, and beta bands were analyzed by two factor repeated measures [Dose (placebo, $20 \mathrm{mg}$, 
$40 \mathrm{mg}$ ) by Time (the 103-minute periods)], analysis of variance (ANOVA) for each electrode using conservative Greenhouse-Geisser, adjustment as recommended for such data (Jennings and Wood 1976; Vasey and Thayer 1987). The cardiovascular measures were analyzed by a two factor repeated measures [Dose (placebo, $20 \mathrm{mg}, 40 \mathrm{mg}$ ) by Time (two baseline and seven values obtained after the injection of the test compound)] ANOVA.

\section{RESULTS}

Both doses of cocaine significantly increased heart rate (Dose: $F=30.97, d f(2,24), p<.0001$; Dose $\times$ Time; $F=13.48, d f(16,192), p<.0001)$, diastolic (Dose: $F=$ 21.58, $d f(2,24), p<.0001$; Dose $\times$ Time: $F=4.16, d f(16$, 192), $p<.01$ ), and systolic (Dose: $F=33.15, d f(2,24)$, $p<.0001$; Dose $\times$ Time: $F=8.28, d f(16,196), p<.0001)$ blood pressure (Figure 1). The difference between the effects of 20 and $40 \mathrm{mg}$ cocaine on cardiovascular measures was small. The postdrug means for "beep" prompt and the VAS responses are listed in Table 3. Both doses of cocaine significantly elevated the responses to the "beep" prompt and scores on the VAS, but no significant differences were observed between the doses.

Cocaine significantly increased EEG beta power (Table 4). The changes from baseline scores at $\mathrm{F}_{\mathrm{pz}}, \mathrm{F}_{\mathrm{z}}$, $F_{3}, F_{7}, C_{z}$, and $C_{3}$ electrodes revealed significant main effects of Dose. Topographical maps for mean EEG beta power are displayed in Figure 2 (bottom). Significant increases in EEG spectral beta power were observed clearly in frontal and central cortical areas. Although both doses of cocaine increased in EEG beta, the effect appeared to wax and wane over time. The increase in beta due to the $40 \mathrm{mg}$ dose of cocaine continued over the 30-minute period. Little or no increase was found after the injection of placebo.

The results for EEG alpha power are shown in Table 5. The main effect of Dose was significant for the change from baseline score at $\mathrm{F}_{\mathrm{pz}}, \mathrm{F}_{\mathrm{z}}, \mathrm{F}_{\mathrm{p} 1}, \mathrm{~F}_{7}$, and $\mathrm{T}_{5}$ electrodes. The significant increase in EEG alpha spectral power occurred in both frontal $\left(\mathrm{F}_{\mathrm{pz}}, \mathrm{F}_{\mathrm{z}}, \mathrm{F}_{\mathrm{p} 1}\right.$, and $\left.\mathrm{F}_{7}\right)$ and temporal $\left(T_{5}\right)$ regions. Mean topographical maps for EEG alpha spectral power are presented in Figure 2 (top). The main effects of Dose and Dose by Time interactions for EEG delta and theta spectra power were not statistically significant.

To explore possible relationships between the EEG alpha and beta and other measures of responses to cocaine, a limited set of correlations was calculated. The correlation of all EEG, self-report, and cardiovascular measures would have resulted in more variables than cases. Therefore, correlations were limited to a subset

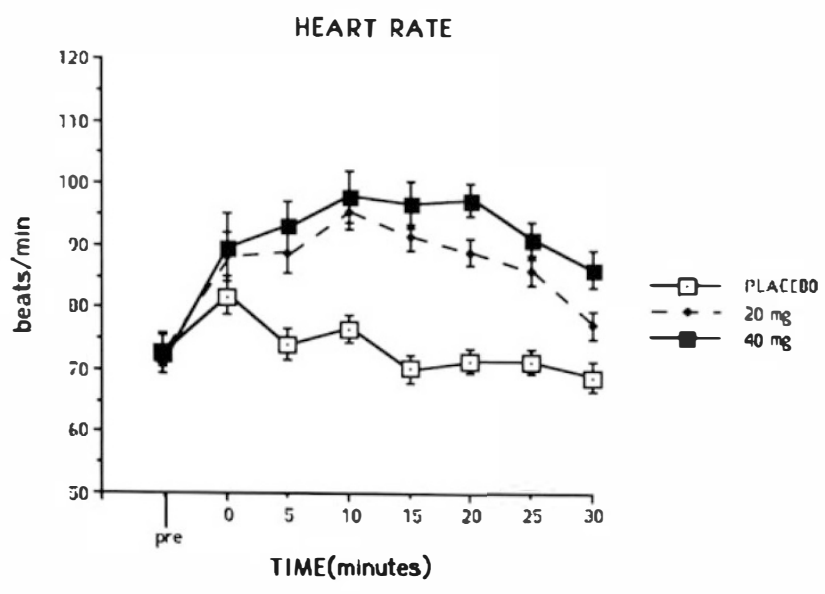

SYSTOLIC BLOOD PRESSURE

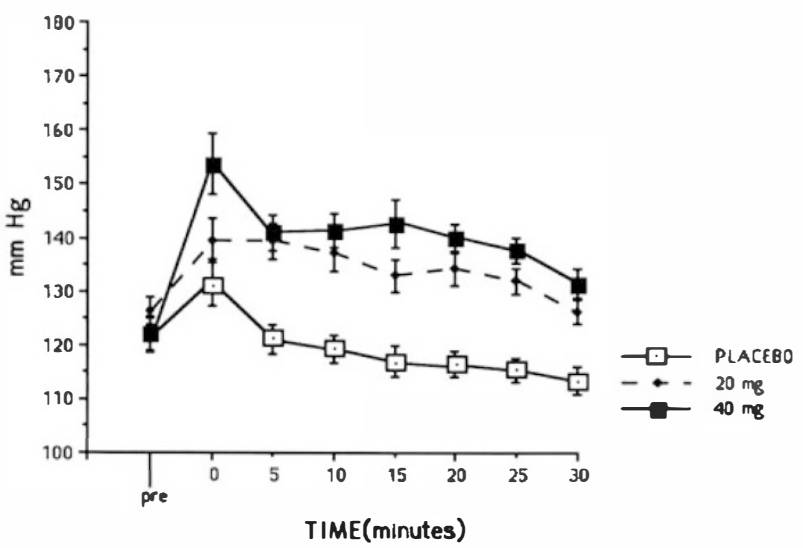

DIASTOLIC BLOOD PRESSURE

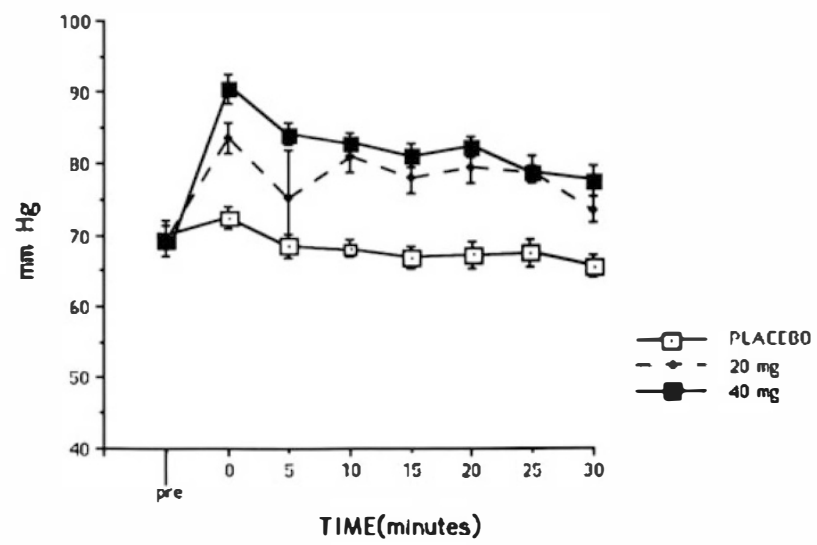

Figure 1. The mean of the cardiovascular measures assessed 30 minutes before and at $1,3,5,10,15,20$, and 30 minutes after injection of placebo, $20 \mathrm{mg}$, and $40 \mathrm{mg}$ cocaine $(n=14)$. The top group of the graph shows heart rate, the middle shows systolic blood pressure and the bottom shows diastolic blood pressure. Bars indicate standard errors. 
Table 3. Subjective Response to "Beep" Prompt and VAS

\begin{tabular}{lccc}
\hline & & \multicolumn{2}{c}{ Cocaine } \\
\cline { 3 - 4 } Subjective Measure & Placebo & $20 \mathrm{mg}$ & $40 \mathrm{mg}$ \\
\hline "Beep"1 & & & \\
Feel drug & $1.8 \pm 1.8^{\star}$ & $19.6 \pm 4.4$ & $21.3 \pm 6.8$ \\
VAS" & $5.1 \pm 5.3^{\star}$ & $38.2 \pm 9.1$ & $49.6 \pm 10.1$ \\
Strong effects & $4.9 \pm 5.2^{\star}$ & $50.0 \pm 10.7$ & $55.0 \pm 11.3$ \\
Good effects & $2.6 \pm 2.4$ & $6.3 \pm 3.3$ & $8.8 \pm 5.1$ \\
Bad effects & $7.6 \pm 7.5^{\star}$ & $48.4 \pm 10.2$ & $51.9 \pm 12.3$ \\
Like drug & $6.8 \pm 6.4^{\star}$ & $43.6 \pm 9.9$ & $47.2 \pm 11.2$ \\
Feel high & $10.4 \pm 10.0^{\star}$ & $63.4 \pm 12.2$ & $56.0 \pm 12.3$ \\
Take again & $5.8 \pm 6.0^{\star}$ & $47.9 \pm 10.8$ & $48.0 \pm 10.0$ \\
Energetic & & &
\end{tabular}

\footnotetext{
${ }^{1}$ The subject was instructed to score his response to the question "How much do you feel the drug?" at the sound of the "beep" prompt.

2 The Visual Analog Scales were presented as seven items, each associated with a $100-\mathrm{mm}$ line, on which the subject scored his response.

"Significant Drug Effect in ANOVA. Placebo was significantly different than both cocaine doses using Bonferroni post hoc test, $p<.05$.
}

of the variables. Correlations of "beep" prompt response, VAS scores, and cardiovascular measures with EEG beta at $F_{p z}$ and with EEG alpha at $F_{p z}$ and $T_{5}$ were calculated at each dose (Table 6). The $\mathrm{F}_{\mathrm{pz}}$ and $\mathrm{T}_{5}$ electrode sites were selected because they showed clear effects of cocaine. At both electrodes, EEG alpha activity was positively correlated with heart rate after the 40-mg dose of cocaine. EEG alpha was also negatively correlated with the VAS item, "use again." Heart rate and systolic blood pressure were significantly correlated with beta power for $40-\mathrm{mg}$ cocaine at $\mathrm{F}_{\mathrm{pz}}$. Another set of correlations was calculated with the placebo values subtracted from each values for the two cocaine sessions on the cardiovascular, self-report, and EEG measures selected in the previous analysis. This procedure attempts to adjust for any bias in data from the placebo session. No significant correlations were observed for either dose and either EEG band.

Table 4. Total EEG Beta Power $\left(\mu \mathrm{V}^{2}\right)$ : Mean Change Scores

\begin{tabular}{|c|c|c|c|c|c|c|c|}
\hline \multirow[b]{2}{*}{ Site } & \multirow[b]{2}{*}{ Placebo } & \multicolumn{2}{|c|}{ Cocaine } & \multirow{2}{*}{$\begin{array}{c}\text { Pooled }^{2} \\
\text { Standard } \\
\text { Deviation }\end{array}$} & \multicolumn{2}{|c|}{$\begin{array}{c}\text { Dose } \\
\text { Main Effect }\end{array}$} & \multirow{2}{*}{$\begin{array}{c}\text { Greenhouse- } \\
\text { Geisser } \\
\text { Probability } \\
\end{array}$} \\
\hline & & $20 \mathrm{mg}$ & $40 \mathrm{mg}$ & & $F(2,13)$ & $p$ & \\
\hline$F_{p z}$ & 3.4 & 24.8 & $\begin{array}{l}245.5 \\
\ldots .11\end{array}$ & 218.2 & 8.721 & 0.0013 & $0.0064^{\star}$ \\
\hline$F_{z}$ & -164.2 & $\begin{array}{l}19.8 \\
\ldots \ldots\end{array}$ & $\begin{array}{r}243.7 \\
\ldots \ldots 1\end{array}$ & 105.5 & 11.053 & 0.0003 & $0.0005^{\star}$ \\
\hline$F_{p 1}$ & -6.6 & 390.3 & 2105.0 & 611.2 & 3.771 & 0.0365 & 0.0734 \\
\hline $\mathrm{F}_{3}$ & -54.2 & $\begin{array}{l}254.0 \\
\ldots \ldots\end{array}$ & $\begin{array}{r}534.3 \\
\ldots \ldots\end{array}$ & 203.4 & 5.230 & 0.0123 & $0.0334^{\star}$ \\
\hline $\mathrm{F}_{7}$ & $\begin{array}{r}-21.2 \\
.\end{array}$ & $\begin{array}{l}161.5 \\
\ldots \ldots\end{array}$ & $\begin{array}{r}419.5 \\
\left.\ldots \ldots\right|^{1}\end{array}$ & 138.4 & 7.786 & 0.0022 & $0.0088^{\star}$ \\
\hline$C_{z}$ & -68.6 & $\begin{array}{l}40.4 \\
\ldots \ldots\end{array}$ & $\begin{array}{l}174.6 \\
\ldots .1\end{array}$ & 92.2 & 5.070 & 0.0138 & $0.0203^{\star}$ \\
\hline $\mathrm{C}_{3}$ & 9.1 & 106.7 & $\begin{array}{l}349.4 \\
\ldots .1\end{array}$ & 117.1 & 5.604 & 0.0095 & $0.0194^{\star}$ \\
\hline $\mathrm{T}_{3}$ & 122.7 & 455.1 & 366.7 & 195.7 & 1.815 & 0.1829 & 0.1956 \\
\hline$P_{z}$ & -120.5 & 4.2 & 198.2 & 145.7 & 2.817 & 0.0781 & 0.0942 \\
\hline$P_{3}$ & -59.8 & 56.0 & 169.2 & 120.7 & 3.028 & 0.0657 & 0.0706 \\
\hline $\mathrm{T}_{5}$ & 18.5 & 415.1 & 460.1 & 340.0 & 2.541 & 0.0982 & 0.1306 \\
\hline $\mathrm{O}_{\mathrm{z}}$ & -27.5 & 48.6 & 201.8 & 99.6 & 2.241 & 0.1265 & 0.1434 \\
\hline $\mathrm{O}_{1}$ & -33.2 & 70.4 & 172.5 & 106.8 & 2.562 & 0.1092 & 0.1092 \\
\hline
\end{tabular}

\footnotetext{
${ }^{1}$ Significant difference between means by Bonferroni post hoc test, $p<(0.05 / 3)=0.0167$. Vertical bars indicate which means differ.

${ }^{2}$ Mean of the three standard deviations.
} 
Table 5. Total EEG Alpha Power $\left(\mu \mathrm{V}^{2}\right)$ : Mean Change Scores

\begin{tabular}{|c|c|c|c|c|c|c|c|}
\hline \multirow[b]{2}{*}{ Site } & \multirow[b]{2}{*}{ Placebo } & \multicolumn{2}{|c|}{ Cocaine } & \multirow{2}{*}{$\begin{array}{c}\text { Pooled }^{2} \\
\text { Standard } \\
\text { Deviation }\end{array}$} & \multicolumn{2}{|c|}{$\begin{array}{c}\text { Dose } \\
\text { Main Effect }\end{array}$} & \multirow{2}{*}{$\begin{array}{c}\text { Greenhouse } \\
\text { Geisser } \\
\text { Probability }\end{array}$} \\
\hline & & $20 \mathrm{mg}$ & $40 \mathrm{mg}$ & & $F(2,13)$ & $p$ & \\
\hline $\mathrm{F}_{\mathrm{pz}}$ & 68.4 & 145.8 & $\begin{array}{r}485.4 \\
\end{array}$ & 116.7 & 6.544 & 0.0050 & $0.0171^{\star}$ \\
\hline$F_{z}$ & 19.8 & 67.1 & $\begin{array}{c}198.8 \\
\ldots .\end{array}$ & 56.1 & 5.825 & 0.0081 & $0.0170^{\star}$ \\
\hline $\begin{array}{l}\mathrm{F}_{\mathrm{p} 1} \\
\mathrm{~F}_{3}\end{array}$ & $\begin{array}{l}90.1 \\
25.0 \\
22.6\end{array}$ & $\begin{array}{r}264.6 \\
266.6 \\
75.1\end{array}$ & $\begin{array}{l}982.8 \\
418.4 \\
217.9\end{array}$ & $\begin{array}{r}256.7 \\
165.7 \\
616\end{array}$ & $\begin{array}{l}4.347 \\
2.460 \\
6.523\end{array}$ & $\begin{array}{l}0.0235 \\
0.1051 \\
0.0051\end{array}$ & $\begin{array}{l}0.0511 \\
0.1251 \\
0.0118^{\star}\end{array}$ \\
\hline & $\begin{array}{c}22.6 \\
\text {. }\end{array}$ & 75.1 & $\begin{array}{r}217.9 \\
\ldots \ldots\end{array}$ & 61.6 & 6.523 & & $0.0118^{\star}$ \\
\hline $\mathrm{C}_{\mathrm{z}}$ & 5.9 & 109.0 & 112.9 & 59.0 & 3.429 & 0.0477 & 0.0505 \\
\hline$C_{3}$ & 26.5 & 61.1 & 158.0 & 55.0 & 3.250 & 0.0550 & 0.0727 \\
\hline$T_{3}$ & 37.3 & 122.4 & 109.5 & 49.9 & 2.959 & 0.0695 & 0.0611 \\
\hline$P_{z}$ & 5.8 & 139.8 & 187.4 & 89.0 & 2.059 & 0.1470 & 0.1645 \\
\hline$P_{3}$ & 18.7 & 95.5 & 158.5 & 57.8 & 2.881 & 0.0741 & 0.0752 \\
\hline$T_{5}$ & 35.6 & 120.6 & 175.6 & 58.6 & 4.743 & 0.0175 & $0.0197^{\star}$ \\
\hline $\mathrm{O}_{\mathrm{z}}$ & 52.6 & 127.0 & 190.7 & 69.8 & 3.070 & 0.0635 & 0.0670 \\
\hline $\mathrm{O}_{1}$ & 65.3 & 227.1 & 212.2 & 70.6 & 2.028 & 0.1518 & 0.1632 \\
\hline
\end{tabular}

${ }^{1}$ Significant difference between means by Bonferroni post hoc test, $p<(0.05 / 3)=0.0167$. Vertical bars indicate which means differ.

${ }^{2}$ Mean of the three standard deviations.

\section{DISCUSSION}

Cocaine increased EEG beta in frontal and central cortical areas and increased EEG alpha in frontal and temporal cortical areas. The increase in beta persisted for 30 minutes after the $40 \mathrm{mg}$ dose of cocaine, but it waxed and waned. The oscillations in the EEG response to both doses of cocaine may represent phasic changes in factors that influence fast EEG activity. The observation that increases in EEG beta were larger than those observed for EEG alpha reinforce and extend the previous reports of cocaine-induced increases in EEG beta (Berger 1937; Herning et al. 1985) and alpha (Berger 1931; Lukas 1993). Likewise, we replicated the effects of cocaine on cardiovascular parameters and selfreported measures of mood (Fischman et al. 1976, 1983; Javaid et al. 1978).

Table 6. Correlations of EEG Measures with Self-Report and Cardiovascular Measures

\begin{tabular}{|c|c|c|c|c|c|c|c|c|c|}
\hline & \multicolumn{3}{|c|}{ Alpha Power at $\mathbf{F}_{\mathrm{pz}}$} & \multicolumn{3}{|c|}{ Alpha Power at $T_{5}$} & \multicolumn{3}{|c|}{ Beta Power at $\mathbf{F}_{\mathrm{pz}}$} \\
\hline & \multirow[b]{2}{*}{ Placebo } & \multicolumn{2}{|c|}{ Cocaine } & \multirow[b]{2}{*}{ Placebo } & \multicolumn{2}{|c|}{ Cocaine } & \multirow[b]{2}{*}{ Placebo } & \multicolumn{2}{|c|}{ Cocaine } \\
\hline & & $20 \mathrm{mg}$ & $40 \mathrm{mg}$ & & 20 mg & $40 \mathrm{mg}$ & & $20 \mathrm{mg}$ & $40 \mathrm{mg}$ \\
\hline $\begin{array}{l}\text { Heart rate } \\
\text { Blood pressure }\end{array}$ & -0.463 & 0.129 & $0.898^{\star}$ & -0.537 & -0.096 & $0.788^{\star}$ & $-0.639^{\star}$ & -0.379 & $0.573^{\star}$ \\
\hline $\begin{array}{l}\text { Systolic } \\
\text { Diastolic }\end{array}$ & $\begin{array}{r}0.294 \\
-0.398\end{array}$ & $\begin{array}{r}0.188 \\
-0.061\end{array}$ & $\begin{array}{l}-0.037 \\
-0.225\end{array}$ & $\begin{array}{l}-0.514 \\
-0.635\end{array}$ & $\begin{array}{r}-0.191 \\
0.186\end{array}$ & $\begin{array}{l}-0.021 \\
-0.398\end{array}$ & $\begin{array}{l}-0.750^{\star} \\
-0.424\end{array}$ & $\begin{array}{r}-0.326 \\
0.040\end{array}$ & $\begin{array}{l}-0.125 \\
-0.491\end{array}$ \\
\hline $\begin{array}{l}\text { Beep: Feel } \\
\text { VAS }(n=10)\end{array}$ & 0.322 & -0.685 & 0.102 & -0.071 & -0.546 & 0.039 & -0.076 & -0.095 & -0.285 \\
\hline $\begin{array}{l}\text { Strong } \\
\text { Good } \\
\text { Bad } \\
\text { Like } \\
\text { High } \\
\text { Use again } \\
\text { Energetic }\end{array}$ & $\begin{array}{l}0.322 \\
0.322 \\
0.252 \\
0.322 \\
0.322 \\
0.322 \\
0.322\end{array}$ & $\begin{array}{l}-0.475 \\
-0.731^{\#} \\
-0.029 \\
-0.548 \\
-0.583 \\
-0.711^{\#} \\
-0.466\end{array}$ & $\begin{array}{l}-0.107 \\
-0.150 \\
-0.257 \\
-0.192 \\
-0.087 \\
-0.136 \\
-0.051\end{array}$ & $\begin{array}{r}-0.071 \\
0.079 \\
-0.071 \\
-0.071 \\
-0.071 \\
-0.071 \\
-0.071\end{array}$ & $\begin{array}{r}-0.318 \\
-0.530 \\
0.448 \\
-0.394 \\
-0.442 \\
-0.453 \\
-0.173\end{array}$ & $\begin{array}{r}-0.273 \\
-0.428 \\
0.151 \\
-0.434 \\
-0.245 \\
-0.340 \\
-0.278\end{array}$ & $\begin{array}{r}-0.076 \\
-0.076 \\
0.373 \\
-0.076 \\
-0.076 \\
-0.076 \\
-0.076\end{array}$ & $\begin{array}{r}0.026 \\
-0.092 \\
0.428 \\
-0.013 \\
-0.012 \\
-0.169 \\
-0.372\end{array}$ & $\begin{array}{r}-0.458 \\
-0.565 \\
-0.290 \\
-0.611 \\
-0.479 \\
0.607 \\
-0.464\end{array}$ \\
\hline
\end{tabular}

$* p<.05, d f=12$.

" $p<.05, d f=8$. 


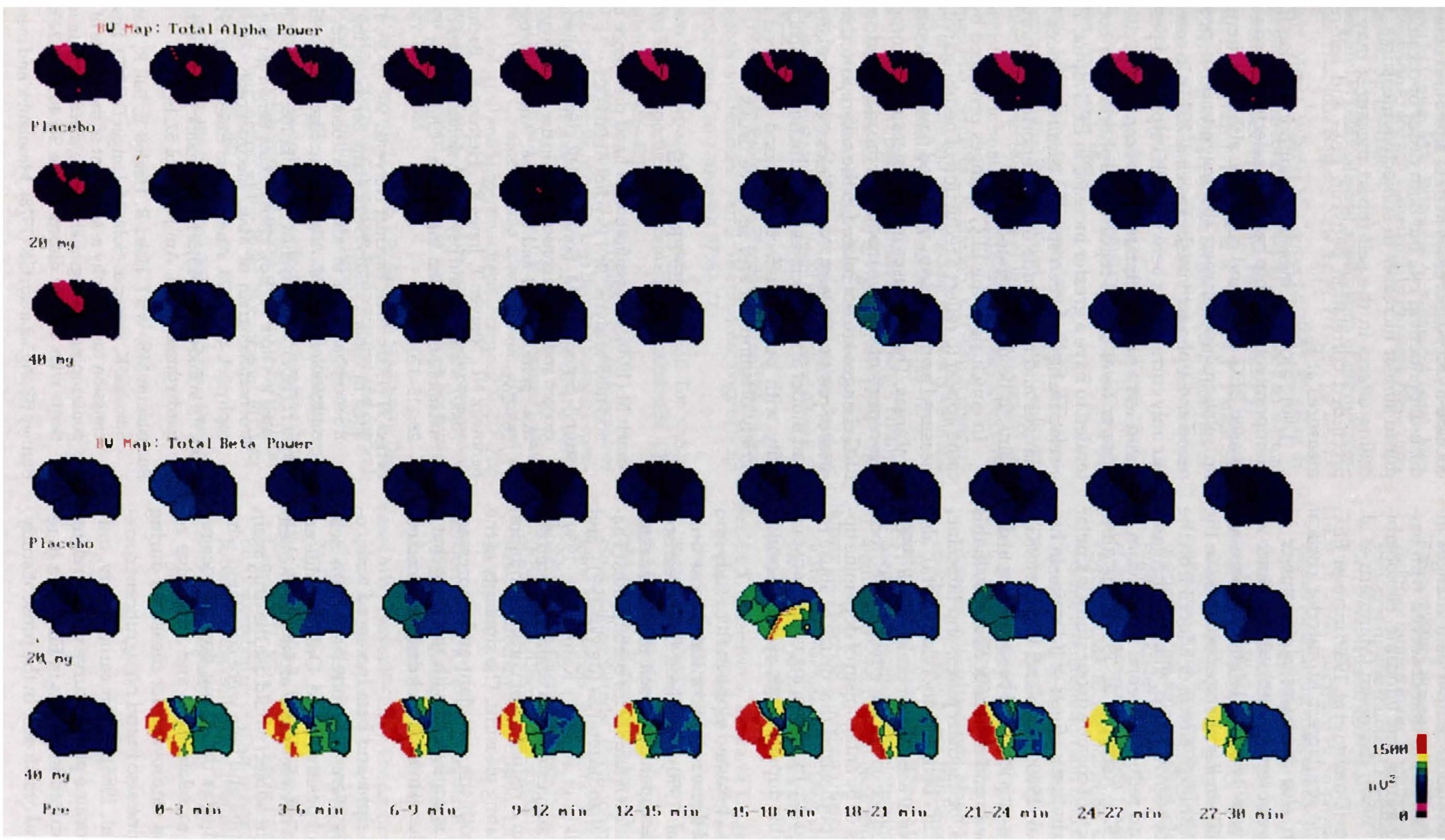

Figure 2. (Top) Topographical maps of total EEG alpha power $(8.4$ to $13.2 \mathrm{~Hz}$ ) averaged over each 3-minute period at each treatment $(n=14)$. The top row of the maps show power after the injection of placebo, and the bottom rows show the effects of $20 \mathrm{mg}$ and $40 \mathrm{mg}$ cocaine, respectively. Each map shows the left hemisphere with the frontal cortex on the left. (Bottom) Topographical maps of total EEG beta power $(13.6$ to $32.8 \mathrm{~Hz}$ ) averaged over each 3-minute epoch at each dose $(n=14)$. The top row of the maps show power after the injection of placebo, and the bottom rows show the effects of $20 \mathrm{mg}$ and $40 \mathrm{mg}$ cocaine, respectively. Each map shows the left hemisphere with the frontal cortex on the left. 
The cortical distribution of EEG beta changes induced by cocaine is similar to that observed with barbiturates, benzodiazepines, and lidocaine. Hexobarbital (Benowitz et al. 1980), diazepam (Manmaru et al. 1989), and midalolam (Domino et al. 1989) increase EEG beta, and the effects are largest in anterior cortical regions. Midalolam also increases alpha power in posterior areas, as we observed with cocaine. Since we only recorded EEG activity on the left hemisphere, we can only suggest that similar changes occurred in the right hemisphere. Although effects of lidocaine on the human EEG havenotbeen reported, this drug increases beta EEG activity and reduces cerebral metabolism in rats (Sabake et al. 1974; Astrup et al. 1981). The duration of the CNS effects of cocaine in our study is similar to that of the antiarrhythmic effects of lidocaine in humans (Harrison et al. 1963; Block and Winkle 1983).

Increases in beta activity could be secondary to decreased cortical activity and metabolic demand. In this regard, barbiturates, benzodiazepines, and lidocaine, which all increase EEG beta activity (vide supra), also reduce cortical neuronal activity (for review, Hall 1990). Cocaine might produce such an effect by its local anesthetic properties or by antagonism of dopamine uptake. It has been hypothesized that drugs of abuse reduce cerebral metabolism by enhancing neurotransmission in the mesolimbic dopaminergic system (London and Morgan 1993).

Increases in EEG beta and alpha in this study and previously reported decreases in cortical glucose utilization (London et al. 1990) and blood flow (Pearlson et al. 1993) were accompanied by self-reports of positive affect. The situation is similar for barbiturates (Theodore et al. 1986), benzodiazepines (de Wit 1991), and amphetamine (Wolkin et al. 1987; Kahn et al. 1989). London et al. (1990) suggested that cocaine-induced euphoria resulted from a reduction of cortical inhibition of limbic areas mediating pleasure. The similarity of the EEG response to both the stimulant and depressant drugs noted above is consistent with the view that a common brain mechanism underlies drug-induced euphoria in humans.

Although EEG alpha and beta increased with cocaine, the increases were not correlated with selfreported measures of positive mood. Only a significant negative correlation between EEG alpha and the selfreports of whether the subject would use the drug again was found. EEG alpha and beta were correlated with heart rate observed after the $40 \mathrm{mg}$ dose of cocaine. Previous attempts to relate EEG and subjective responses or EEG and cardiovascular measures during intoxication by cocaine also found no significant correlations (Herning et al. 1985). In our earlier study, only the area under the cocaine plasma curve was correlated with the cocaine-induced increases in EEG beta in response to both IV and oral doses. In the present study, cocaine-induced increases in EEG alpha and beta were dose-dependent at $F_{p z}$, but both doses of cocaine produced similar increases in subjective measures. Such ceiling effects in the self-report measures may have precluded correlation between EEG and self-report measures at $\mathrm{F}_{\mathrm{pz}}$.

Using a joystick measure of euphoria, Lukas found a temporal relationship between selected epochs of increased EEG alpha and euphoria, although there was no relationship between the magnitude of positive mood and alpha activity (Lukas et al. 1993). In contrast, our only correlations between EEG alpha and positive mood were negative but not significant. Subjects with a lower level of self-reported euphoria after cocaine tended to have a greater increase in EEG alpha. Thus, a relationship between specific cocaine-induced EEG changes and magnitude of self-reported euphoria remains to be demonstrated.

In conclusion, the EEG changes produced by cocaine appear to reflect a reduction of neural activity, as measured by metabolism and blood flow in anterior cortical areas. The increases in EEG measures accompany self-reports of positive mood, but the magnitude of the EEG changes are not related to the self-reported intensities of positive feelings. Nonetheless, our working human model also associates the reduction of cortical activity with positive effects on mood produced by a variety of stimulant and sedative drugs.

\section{REFERENCES}

Annett M (1970): A classification of hand preference by association analysis. Br J Psychol 61:303-321

Astrup J, Sorenson PM, Sorenson HR (1981): Inhibition of oxygen and glucoseconsumption in the dog by hypothermia, pentobarbital and lidocaine. Anesthesiology 55: 263-268

Benowitz NL, Nguyen T, Jones RT, Herning RI, Bachman J (1980): Metabolic and psychophysiologic studies of cannabidiol-hexobarbital interaction. Clin Pharm Therap 28:115-120

Berger H (1931): Arch Psychiat Nervenkr 94: 16-30. Translated in Gloor P (Ed) (1969): Hans Berger on the Electroencephalogram of Man. Electroenceph Clin Neurophysiol, Suppl 28, Amsterdam: Elsevier, pp 95-132

Berger H (1937): Arch Psychiat Nervenkr 106: 577-584. Translated in Gloor P. (Ed), (1969): Hans Berger on the Electroencephalogram of Man. Electroenceph Clin Neurophysiol, Suppl 28, Amsterdam: Elsevier, pp 291-297

Block PJ, Winkle RA (1983): Hemodynamic effects of the antiarrhythmic drugs. Am J Cardiol 52:14-23

Buchsbaum MS, Wu J, Haier R, Hazlett E, Ball R, Katz M, Sokolski K, Lagumas-Solar M, Langer D (1987): Positron emission tomography assessment of the effects of benzodiazepines on regional glucose metabolic rate in patients with anxiety disorder. Life Sci 40:2993-2400

Bunney BS, Aghajanian GK(1978): Mesolimbic and mesocor- 
tical dopaminergic systems: Physiology and pharmacology. In Lipton MA, DiMascio A, Killam FA (eds), Psychopharmacology: A Generation of Progress, New York: Raven, pp 159-169

Chamberlin H (1985): Musical applications of microprocessors. HasbrookHeights, New Jersey:Hayden, pp 144-458

de Wit H, Metz J, Wagner N, Cooper M (1991): Effects of diazepam on cerebral metabolism and mood in normal volunteers. Neuropsychopharmacology 5:33-41

Domino EF, French J, Pohorecki R, Galus CF, Pandit SK (1989): Further observations on the effects of subhypnotic doses of midazolam in normal volunteers. Psychopharmacol Bull 25:460-465

DSM-III, Third Diagnostic and Statistical Manual, American Psychiatric Association (1980): Washington, DC: American Psychiatric Press.

Fischman MW, Schuster CR, Resnekov L, Shick JFE, Krasnegor NA, Fennel W, Freedman, DX (1976): Cardiovascular and subjective effects of intravenous cocaine administration in humans. Arch Gen Psychiatry 33:983-989

Fischman MW, Schuster CR, Hatano, Y (1983): A comparison of subjective and cardiovascular effects of cocaine and lidocaine. Pharmacol Biochem Behav 18:123-127

Foster NL, VanDerSpek AF, Aldrich MS, Berent S, Hichwa RH, Sackeliares JC, Gilman S, Agranoff BW (1987): The effect of diazepam sedation on cerebral glucose metabolism in Alzheimer's disease as measured using positron emission tomography. J Cereb Blood Flow Metab 7: 415-420

Hall R (1990): Brain Protection: Physiological and pharmacological considerations. Part II: The pharmacology of brain protection. Can J Anaesth 37:62-77

Harrison DC, Sprouse BJ, Morrow AG (1963): The antiarrhythmic properties of lidocaine and procainamide. Circulation 28:486-491

Herning RI, Jones RT, Hooker WD (1985): Cocaine increases EEG beta: A replication of Hans Berger's historic experiments. Electroenceph Clin Neurophysiol 60:470-477

Javaid JI, Fischman MA, Schuster CR, Dekirmenjian H, Davis JM (1978): Cocaine plasma concentration: Relation to physiological and subjective effects. Science 200:227-228

Jennings JR, Wood CC (1976): The epsilon adjusted procedure for repeated analysis of variance. Psychophysiology 17:367-384

Kahn DA, Prohovnik I, Lucas LR, Sackeim HA (1989): Dissociated effects of amphetamine on arousal and cortical blood flow in humans. Biol Psychiatry 25:755-767

London ED, Morgan MJ (1993): Positron emission tomographic studies on the acute effects of psychoactive drugs on brain metabolism and mood. In London ED (ed), Imaging Drug Action in the Brain, Boca Raton, FL; CRC Press, pp 265-280

London ED, Cascella NG, Wong DF, Phillips RL, Dannals
RF, Links JM, Herning RI, Grayson R, Jaffe JH, Wagner HN Jr (1990): Cocaine-induced reduction of glucose utilization in human brain: A study using positron emission tomography and [fluorine 18]-fluorodeoxyglucose. Arch Gen Psychiatry 47:567-574

Lukas SE (1993): Advanced electrophysiological imaging techniques for studying drug effects. In London ED (ed), Imagining Drug Action in the Brain, Boca Raton, FL: CRC Press, pp 253-264

Manmaru S, Matsura M (1989): Quantification of benzodiazepine-induced topographic EEG changes by a computerized wave from recognition method: Application of principal component analysis. Electroenceph Clin Neurophysiol 72:126-132

McLellan AT, Cacciata J, Griffith J, McCahn P, O'Brien CP (1985): Guide to the addiction severity index: Background, administration and field testing results. Washington, DC: U.S. Printing Office, Treatment Research Report DHHS Publication Number ADM 85-1419

Pearlson GD, Jeffery PJ, Harris GJ, Ross CA, Fischman MW, Camargo EE (1993): Correlation of acute cocaine-induced changes in local cerebral blood flow with subjective effects. Am J Psychiatry 150:495-497

Perrin F, Pernier J, Bertrand O, Giard MH, Echallier JF (1987): Mapping of scalp potentials by surface spline interpolation. Electroenceph Clin Neurophysiol 66:75-81

Robins LN, Helzer JE, Coughan J, Ratcliff KS (1981): National Institute of Mental Health Diagnostic Interview Schedule: Its history, characteristics and validity. Arch Gen Psychiatry 38:381-389

Sakabe T, Maekawa T, Ishikawa T, Takeshita H (1974): The effects of lidocaine on canine cerebral metabolism and circulation related to the electroencephalogram. Anesthesiology 40:433-441

Siggins GR (1978): Electrophysiological role of dopamine in striatum: Excitatory or inhibitory? In Lipton MA, DiMascio A, Killam KF (eds), Psychopharmacology: A Generation of Progress. New York: Raven, pp 143-157

Sokoloff L (1972): Circulation and energy metabolism of brain. In Siegal GJ, Albers RW, Katzman R, Agranoff BW (eds), Basic Neurochemistry, Boston: Little, Brown and Co., pp 338-413

Theodore WH, DiChiro G, Margolin R, Porter RJ, Brooks RA (1986): Barbiturates reduce human cerebral glucose metabolism. Neurology 36:60-64

Vasey MW, Thayer JF (1987): The continuing problem of false positives in repeated measures ANOVA in psychophysiology: A multivariate solution. Psychophysiology 24:479-486

Wolkin A, Angrist B, Wolf A, Brodie B, Wolkin B, Jaeger J, Cancro GU, Rotrosen J (1987): Effects of amphetamine on local cerebral metabolism in normal and schizophrenic subjects as determined by positron emission tomography. Psychopharmacology 92:241-246 